\title{
Artur Pacewicz
}

Uniwerytet Wrocławski

(iD https://orcid.org/0000-0001-8863-7900

\section{Plato and the Classical Theory of Knowledge*}

\section{Platon a klasyczna teoria wiedzy}

\begin{abstract}
Abstrakt: W niniejszym artykule podjęta zostaje kwestia, w jakim stopniu można mówić o klasycznej teorii wiedzy w filozofii Platona. Punktem wyjścia są uwagi poczynione przez J. Woleńskiego w jego książce Epistemologia. Obszarem badawczym jest zasadniczo całość twórczości filozoficznej założyciela Akademii, ze szczególnym uwzględnieniem pism: Obrona Sokratesa, Gorgias, Menon, Politeia, Teajtet, Timajos i świadectwa dotyczące tzw. niespisanej nauki Platona.
\end{abstract}

Słowa klucze: Platon, wiedza

\section{Introduction}

In his Epistemology, Jan Woleński introduces a classical definition of knowledge: it is a true, justified judgement (conviction). It was allegedly created by Plato, who considers it in the Theatetus only to reject it in the end. ${ }^{1}$ In modern times, this conception has been represented by such phi-

* This is a revised version of the paper $O$ "klasyczności" klasycznej koncepcji wie$d z y$, which was published in: Wiedza. Ed. D. LeszCZYŃsKi. Wrocław 2013, pp. 9-29.

1 J. WoleńsKi: Epistemologia, vol. I: Zarys historyczny i problemy metateoretyczne. Kraków 2000, p. 26. 
losophers as B. Russell, G.E. Moore, A.J. Ayer and R.M. Chisholm. ${ }^{2}$ In reference to Plato, Woleński also presents the distinction (introduced in the Republic) between knowledge (epistēmē) and belief (doxa), their divisions and foundation in Plato's ontology. Plato's entire contribution is summarized as follows:

[Plato] introduced many important views and innovations to epistemology. In general, he developed a consistent system of rationalist theory of cognition. [...] Plato's rationalism has two dimensions: methodological, i.e., a radical version of apriorism, and genetic, i.e., innatism. [...] Plato was also a radical fundamentalist, i.e., he understood knowledge as a pyramid with the unshakeable foundations. [...] He also left behind the worrying ambiguity of the term "knowledge," although he used the term episteme unambiguously. [...] Finally, Plato initiated irrationalism because the noetic cognition was essentially a kind of contemplation. ${ }^{3}$

The aim of this paper is, first of all, to develop Woleński's general statements in relation to Plato's conception of knowledge, which will allow for a fuller understanding of the "classic" character of the classical concept of knowledge. Secondly, Woleński's approach is shown to be misleading to some extent when the entire philosophical opus of the founder of the Academy is taken into consideration. However, before the arguments are presented, two preliminary issues should be considered.

Firstly, J. Woleński classifies Plato's views by means of a series of abstracts (-isms), and two of them — rationalism ${ }^{4}$ and irrationalism - might suggest that Plato's thought contradicts itself. This statement in itself is not surprising, especially when one takes into account the literary character of Plato's writings, but it can perhaps astonish when one considers the fact that, according to Woleński, Plato created a consistent system of rationalist theory of cognition. This problem arises perhaps from the application of later abstract concepts to thought that appeared (much) earlier and the

2 J. Woleński: Epistemologia, vol. II: Wiedza i poznanie. Kraków 2001, pp. 23-24. The Theaetetus is frequently quoted in the context of the classical theory of knowledge, see, e.g., M. Williams: Skepticism. In: The Blackwell Guide to Epistemology. Eds. J. Greco, E. Sosa. Malden-Oxford 1999, p. 63; R. Audi: Epistemology. A Contemporary Introduction to the Theory of Knowledge. London-New York 1998, p. 210.

3 J. Woleński: Epistemologia, vol. 1, pp. 28-30 (trans. A.P.).

4 "Rationalism" is naturally an ambiguous term, see. E. Curley: Rationalism. In: A Companion to Epistemology. Eds. J. Dancy, E. Sosa, M. Steup. Malden-OxfordChichester 2010, pp. 659-663. J. Woleński confronts it with "empiricism"; see J. WoLEŃsKi: Epistemologia, vol. II, p. 87 ff. 
fact that the latter cannot be integrated into the contemporary model. This applies not only to the various types of "-isms." It can also problematize (especially from a contemporary point of view) whether there are "theories" in ancient philosophy (which could be understood, for example, as axiomatic systems or sets of models ${ }^{5}$ ), or whether ancient philosophical conceptions are "systems" (and, if so, in what sense — static or dynamic, for example ${ }^{6}$ ).

Secondly, attention should be paid to the interpretative problems that arise from Plato's dialogues themselves. As has already been mentioned, they are literary works, which permit the use of colloquial, often ambiguous language, but this does not mean they must necessarily be inaccurate. Already in antiquity, there were problems with the interpretation of Plato's works - subtitles were added to the dialogues to indicate the proper object of the debate and there were attempts at determining the general nature of the discussion. ${ }^{7}$ Later, a biographical model was cultivated, which, along with the development of philology, was transformed into a dynamic developmental model. Thanks to stylometric research, the dialogues were divided into three chronological groups; these groups represented three periods of Plato's philosophy (early, middle and late), and the process that linked these groups was referred to as "progress" or "evolution." ${ }^{8}$ However, this approach has been criticised and a so-called "unitary" interpretation of Plato has arisen. According to it, either the entire opus of the founder of the Academy contains a coherent philosophical conception, or at least some areas of Plato's philosophy (for example, the theory of the Good or his ethics ${ }^{9}$ ) are consistent (i.e., they constitute a unity). Another version of the "unitary approach" recommends that every dialogue should be researched independently and without any material connection to other works. ${ }^{10}$ In this context,

5 W.C. SAlmon: Theory. In: A Companion to Epistemology, p. 768.

6 For more on the introduction of the term "system" to the history of philosophy, see L. Catana: The Historiographical Concept "System of Philosophy." Its Origin, Nature, Influence and Legitimacy. Leiden-Boston 2008.

7 See Diogenes Laertius: Vitae philosophorum, III 57-62.

8 See, e.g., L. Brandwood: Stylometry and Chronology. In: The Cambridge Companion to Plato. Ed. R. Kraut. Cambridge 1992, pp. 90-120; W. Stróżewski: Wykłady o Platonie. Ontologia. Kraków 1992, pp. 11-26; A. PACEwicz: O ewolucyjnym charakterze filozofii Platona. In: Philosophiae Itinera. Eds. A. PACEWICz, A. Olejarczyk, J. JASKóŁA. Wrocław 2009, pp. 501-518.

9 See, e.g., G.R. Morrow: Plato's Cretean City, A Historical Interpretation of the Laws. Princeton 1993, p. XXV; M. ERLER: "Socrates in the Cave." Argumentations as Therapy for Passions in Gorgias and Phaedo. In: Plato Ethicus. Philosophy is Life. Eds. M. Migliori, L.M. Napolitano Valditara. Sankt Augustin 2004, p. 119.

10 See, e.g., R.B. Rutherford: The Art of Plato. Ten Essays in the Platonic Interpretation. Harvard 1995, pp. 23-25; G. ReAlE: Storia della filosofia antica. 
Woleński's opinion that Plato used the term "knowledge" unambiguously seems to suggest a unitary interpretation, although it is also possible that his interpretation is based solely on the Theaetetus and the Republic.

\section{Apology}

In the Apology of Socrates, the term "knowledge" appears only once and it is used in connection with the philosophy of Anaxagoras ( $A p$. 19c 6). Though Socrates refuses to have this kind of knowledge, he does not condemn it. People with knowledge (epistemōn) are also mentioned, and Socrates considers such persons craftsmen (cheirotechnas) because they "have knowledge of many beautiful things" (Ap. 22d). This kind of knowledge is limited to a certain object (e.g., shoemaking) or to a certain discipline (e.g., handicraft), and there are probably many such subjects/ disciplines. It is known that Socrates considers it illegitimate to extend knowledge from one field to another. Craftsmen make the mistake that acting according to the knowledge (and therefore according to certain rules) in a given scope, they believe that they can also act in the field of the greatest (ta megista - Ap. 22d) or the most important matters (ta pleistou axia $A p$. 30a). The acceptance of craft knowledge as a model also allows for the recognition of the following things as features of knowledge: (1) possibility and ability to teach it; (2) possibility and ability to explain it. ${ }^{11}$

Both conditions show that knowledge is understandable. But what is the greatest and most important matter? It is a virtue (aretē). It seems then that knowledge is divided into two disjunctive scopes which can be called "technical" and "moral." The latter is not an indivisible whole because Socrates claims that there is a person who is an expert on human virtue (anthrōpine aretē) and he or she can perform the function of an educator (Ap. 20b). Socrates seems to suppose that there are two kinds of virtues (human and non-human) and they are the subject of two kinds of moral knowledge. The difference between them can be seen by referring to the state that arises as

Vol. II. Milano $1988^{6}$, p. XVIII; G.A. Press: Preface. In: Plato's Dialogues. New Studies \& Interpretations. Ed. G.A. Press. Lanham 1993, pp. VII-IX.

11 This feature appears during Socrates's encounter with the poets (Ap. 20c) - they were not able to explain their own texts. 
a result of knowledge, which is called "wisdom" (sophia) $)^{12}$ : "What is probable, gentlemen, is that in fact the god is wise and that his oracular response meant that human wisdom is worth little or nothing..."13

God has the highest wisdom, which probably consists in the absolutely true (real - tōi onti - Ap. 23a 5) knowledge of virtue. ${ }^{14}$ Humans are in possession of a lower type of wisdom that has both a negative and positive dimension. The first one consists in the recognition that no one has divine moral knowledge. It is achieved by the application of several procedures, such as questioning (ereunan), researching (zetein, exetazein) or refuting (elegchein ${ }^{15}$ ), to those views which seem to claim to be full knowledge. The semi-positive aspect comes from this recognition. It allows someone to claim that he or she has better knowledge (i.e., is wiser ${ }^{16}$ ) than someone who does not recognize the lack of knowledge. But the fully positive facet appears in the form of the set of moral statements, which are scattered across Apology. Here are the examples:

And surely it is the most blameworthy ignorance to believe that one knows what one does not know. [...] I do know, however, that it is wicked and shameful to do wrong, to disobey one's superior, be he god or man. I shall never fear or avoid things of which I do not know, whether they may not be good rather than things that I know to be bad (Ap. 29b 1-9).

It is not clear, however, what status these statements have within the framework of human knowledge. It seems that they are not "revealed god's truths," since they bear the term of "conformity with [divine] law"

12 Plato uses the terms "knowledge," "wisdom" and "skill" interchangeably; see T.C. Brickhouse, N.D. Smith: Plato’s Socrates. Oxford 1994, p. 7; P. Woodruff: Plato's Early Theory of Knowledge. In: Ancient Greek Epistemology. Ed. S. Everson. Cambridge 1990 , pp. $60-84$.

13 Pl., Ap. 23a 5-6; all quotations from the Apology are in G.M.A. GrubE's translation.

14 This is presumably the "technical" knowledge of virtue - C.D.C. REEvE: Socrates in the Apology. An Essay on Plato's Apology of Socrates. Indianapolis 1989, p. $33 \mathrm{ff}$.

15 On the classical interpretation of the elenchus see R. Robinson: Plato's Earlier Dialectic. New York 1941, pp. 7-20; G. Vlastos: The Socratic Elenchus. "Oxford Studies in Ancient Philosophy" 1983, no. 1, pp. 27-58; R. KRaUt: Comments on Gregory Vlastos, "The Socratic Elenchus." "Oxford Studies in Ancient Philosophy" 1983, no. 1, pp. 59-70.

16 On the moral level, it also enables one to avoid the greatest vice called hubris. This is why the greatest good for man is to ponder and discuss (peri aretēs logous poieisthai) virtue every day, i.e., to examine oneself and others in this area (Ap. 38a). 
$\left(\right.$ themiton $^{17}$ ), nor the subjective convictions of Socrates, since, in turn, he clearly defines these, using the verb "to be convinced" (dokein) ${ }^{18}$

To sum up, knowledge is always knowledge about something, which determines its two basic scopes — craftsmanship (technē) and moral knowledge - of which the latter is higher and better than the former. The former is fully accessible to man, while the latter can only be fully possessed by a deity. A man should first of all realize that he or she does not have such full knowledge and compared to the wisdom of god, their knowledge in this area is quite scanty. The relationship between techne and moral knowledge can be called a one-way transitive, i.e., to be technically wise cannot guarantee to be morally wise, but to be morally wise can guarantee to be technically wise. ${ }^{19}$

\section{Gorgias - Meno}

Two other dialogues of Plato's bring slightly different epistemological distinctions. One of the topics in Gorgias (Grg. 254d ff.) is the discussion on the status of rhetoric. There is a distinction there between knowledge (mathēsis, epistēmē) and trust/faith (pistis), the first of which is characterized by truthfulness, while it is possible for the second to be both true and false. Both can be sources of a conviction (peithō) and on the basis of both elements, the practical effect of an action can be achieved. Mathēsis

17 E.g., Pl., Ap. 21b 3-7: "Whatever does the god mean? What is his riddle? I am very conscious that I am not wise at all; what then does he mean by saying that I am the wisest? For surely he does not lie; it is not legitimate [themiton] for him to do so."

18 E.g., ibid. 35b 9-c 2: "Quite apart from the question of reputation, gentlemen, I do not think [dokein] it right to supplicate the jury and to be acquitted because of this, but to teach and persuade them." It seems also that these are not any beliefs, but rather serious and non-hypothetical ones; see Pl., Grg. 495a-b: "You're wrecking your earlier statements, Callicles, and you'd no longer be adequately inquiring into the truth of the matter with me if you speak contrary to what you think. [...] Do you really assert these things, Callicles?" (translated by D.J. ZeYL); Pl., Prt. 331c—d: "Don't do that to me! It's not this 'if you want' or 'if you agree' business I want to test. It's you and me I want to put on the line, and I think the argument will be tested best if we take the 'if' out." (translated by S. LOMBARdo and K. BeLL).

19 This feature can be inferred from Socrates' statement that "Wealth does not bring about excellence, but excellence makes wealth and everything else good for men, both individually and collectively" (Ap. 30b 2-4). 
is understood as something learned (memathēkenai - Grg. 454c 8-9) and the examples of professions (doctor, shipbuilder, bricklayer, military commander - Grg. $455 \mathrm{~b}-\mathrm{c}$ ) show that for Plato, the conditions required for something to qualify as knowledge are closely related to the conditions imposed on a skill (technē). Rhetoric seems to fulfil the conditions of being a skill (knowledge), i.e., it can be learned and taught to others, it has a practical application and works according to certain rules, but while other technai have their own specific object, rhetoric appears to be an objectless action (the possible object of rhetoric can be perhaps language itself). ${ }^{20}$ If it enters into the scope of another human activity, it oversteps its authority, which can have disastrous consequences (as in the courts, e.g., where one seeks justice), especially when the rhetorician possesses only false beliefs. ${ }^{21}$ The Gorgias leaves two important questions about knowledge unsettled: (1) the status of true faith (pistis alêthēs) ${ }^{22}$ and (2) whether knowledge about moral values is achievable. As to the second question, the mythological ending of the dialogue and the use of allegorical argumentation may suggest that moral knowledge is given to human beings to a very limited extent (perhaps myths represent the pistis alethēs).

In Meno (Men. 82b ff.), there is the famous experiment with the slave who, without any mathematical education and on the basis of questions asked by Socrates, "discovers" some mathematical propositions. According to Socrates, this is possible as the soul is immortal and possesses the innate truths which are forgotten because of its incarnation and should be recalled during its life on Earth. ${ }^{23}$ Socrates generally describes the effects of the slave's reasoning as "true belief" (doxa alethess). ${ }^{24}$ When one re-

20 Pl., Grg. 459b 7-c 2: "Oratory doesn't need to have any knowledge of the state of their subject matters; it only needs to have discovered some device to produce persuasion in order to make itself appear to those who don't have knowledge that it knows more than those who actually do have it."

${ }^{21}$ See ibid., 458a 8-b 1: "I don't suppose there's anything quite so bad for a person as having false belief about the things we're discussing right now."

${ }^{22}$ It is worth mentioning here that in Parmenides's poem pistis alethēs is the opposite of the beliefs of mortals (doksai brotōn); DK 28 B 1, 30 (H. Diels, W. Kranz, Die Fragmente der Vorsokratiker, vol. I. Berlin 1951).

${ }_{23}$ W.K.C. Guthrie (The History of Greek Philosophy. Vol. IV: Plato: the Man and His Dialogues. Earlier Period. Cambridge 1975, p. 255) believes that in the Meno, the difference between the a priori knowledge and the empirical knowledge is articulated for the first time.

${ }^{24}$ There is a discussion on the very difficult question of whether the distinction between knowledge and true opinion is accepted in the so-called "Socratic" dialogues or not. For those who accept it, see: E.R. DodDs (Plato: Gorgias. Ed. E.R. DodDs. Oxford 1959, p. 206); T. Irwin (Plato's Moral Theory. The Early and Middle Dialogues. Oxford 1977, p. 40; Plato's Ethics. Oxford 1995, pp. 27-28, 141-143); L. TARÁN (Platonism 
peats a recollection over and over again, it can lead to accurate knowledge (akribōs - Men. 85c-d). True or right (orthē) belief can be no worse lodestar (hēgemōn) for right action (orthōs prattein) than knowledge, so it is also no less useful than knowledge. The first difference between true belief and knowledge most likely consists in the degree of their permanence. The former has a tendency to leave the human soul, which is the cause of the fact that the goal of an action can only be achieved from time to time, while the latter is something permanent and guarantees consistent success. The second difference is the possibility to learn it - only knowledge can be taught and learned (Men. 97b-e). Though true beliefs are the starting point and basis for knowledge, they have to be connected by causative reasoning (atias logimōi) and enhanced by the anamnetic procedure (anamnēsis Men. 98a 3-4). ${ }^{25}$ As a result, it is possible not only to answer the question about the cause of a being, but also to know the whole logical structure justifying that something is just such. Thus, taking into account the fact that Plato considers mathematics, anamnesis and extrasensory sources of cognition, it can be concluded that the basis of knowledge is a priori (although the ontological status of this basis is not entirely clear), the structure is characterized by accuracy, i.e., it is most likely non-contradictory, and the only criterion and producer of knowledge is reason (phronesis). One can see, then, that this is not the same approach to knowledge as before. The paradigm of knowledge is not techne but mathematics. Morality (aretē) is excluded from the area of knowledge, but not because of its nature. According to Socrates, the argument against identifying knowledge with virtue is that there is no teacher of the latter (Men. 98e). This argumenta-

and Socratic Ignorance. In: Platonic Investigations. Ed. D.J. O’MeARA. Washington 1985, p. 88) and H.H. Benson (Socratic Wisdom. Model of Knowledge in Plato's Early Dialogues. Oxford 2000, p. 93). For those who reject it, see: C.H. KaHN (On the Relative Date of the Gorgias and the Protagoras. "Oxford Studies in Ancient Philosophy" 1988, no. 6, pp. 87-88); A. Nehamas (Socratic Intellectualism. "Proceedings of the Boston Area Colloquium in Ancient Philosophy" 1986, no. 2, p. 282), P. Woodruff (Plato's Early Theory of Knowledge, pp. 80-81) and T. PENner (What Laches and Nicias Miss - and Whether Socrates Thinks Courage Merely a Part of Virtue. "Ancient Philosophy" 1992, no. 12 , p. 151, note 18 ).

25 The procedure of anamnesis appears also in Phaedo, where it is indicated that it can assume a stronger, more correct form, i.e., the one that can lead to knowledge based on innate, general concepts, or a weaker one which is based solely on the sensual cognition. In this dialogue, knowledge is a postulate - the goal of human aspiration, which can be fully achieved only after death, i.e., after separation from all sensual determinants. It is worth mentioning here that in the Phaedo, there is also a demand to present a justification (logon dounai) for the proposed theses. For more on this, see A. PACEWICZ: Wisdom - Knowledge - Belief. The Problem of Demarcation in Plato's "Phaedo." "Studia Philosophica Wartislaviensia. Supplementary Volume. English Edition” 2013, pp. 11-23. 
tion, however, can be read in a way that is related to the historical context of the dialogue - there are no such teachers so far (until the time of the conversation between Meno and Socrates), which does not mean that they cannot appear in the future, and if this happened, it would be possible to identify virtue with knowledge. Moral ideas expressed in the past by eminent persons (such as Solon for example) are not the result of reason but of a divine activity similar to poetic work (theia moira - Men. 100a). Some of these ideas can be considered as true beliefs and by philosophical research, they can probably become knowledge. ${ }^{26}$

It follows from the above that one of the possible ways of presenting what knowledge was for Plato is to refer knowledge to other cognitive states - to faith (pistis) and belief (doxa). This picture of epistemological states is continued and deepened in the Republic. In Book V (R. 476a480a), Plato proposes the thesis that an elite possessing philosophical knowledge should rule, and he introduces a distinction between knowledge, ignorance and opinion. As a result of gnōsis, knowledge is clear (saphēs), and it has as its object what is (to on) or what is in a "pure" way (eilikrinōs - R. 477a 7), while the object of ignorance is what is not (to me on). ${ }^{27}$ If something that is is panteloss, ${ }^{28}$ then its cognition is also pantelōs. But

${ }^{26}$ This seems to be the fundamental and the most important difference between the Gorgias and the Meno. See C.H. KAHn: Did Plato Write Socratic Dialogues. "Classical Quarterly" 1981, no. 31, p. 312, note 16; C.H. KaHN: On the Relative Date, p. 77, note 18; H.H. Benson: Socratic Wisdom, p. 94, note 156.

${ }^{27}$ In both cases, Plato uses a noun which is formed from the participle of the present tense of the verb einai ("to be"). I.M. Crombie (An Examination of Plato's Doctrines. Vol. I: Plato on Man and Society. London 1962, p. 42) argues that there are four meanings of the verb 'to be' in Plato's dialogues: existence, genuineness, stability and ultimacy. On the different meanings of the verb, see C.H. KAHN (A Return to the Theory of the Verb Be and the Concept of Being. In: C.H. KAHN: Essays on Being. Oxford 2009, pp. 115-116), who writes: "we can say that Plato has only one concept of Being, expressed by einai, ousia and on, a concept that will cover the notions of existence, predication, identity, truth, and perhaps more. [...] Of course for analytical purposes we need to introduce such distinctions into our hermeneutical meta-language in commenting on Plato's text. But we must be alert to the discrepancy between such modern distinctions and what is actually under discussion in the ancient texts. It is we who are fusing the two meanings, not Plato or Aristotle." See also R.C. Cross, A.D. Woozley: Plato's Republic. A Philosophical Commentary. London 1964, p. 45; J. AnNAs: An Introduction to Plato's Republic. Oxford 1981, pp. 196-198. The model object of knowledge is the beauty itself (kalon auto) or the idea of the beauty (idea autou kallous - R. 479a 1-2) and it is something that is one (hen) and absolute (aei kata tauta hōsautōs on $-R$. 479e 7-8). By contrast, the object of belief is characterized by plurality and relativeness, e.g., beautiful sounds or colours.

28 The precise translation and interpretation of this adverb is difficult: W. WITWICKI (Platon: Państwo, Kęty 2001): “doskonale”; I.M. Crombie (An Examination of Plato's Doctrines. Vol. II: Plato on Knowledge and Reality. London-New York 1963, p. 56): 
human cognitive activity cannot, according to Plato, be correctly described by the dichotomy of knowledge and ignorance, because there is something between (metaxu) them. This "something" is a belief and its object is and is not at the same time. This object is not pantelos, but it is also not nonbeing. ${ }^{29}$ It is also recognized more clearly than non-being but less clearly than being. An example of knowledge's object is beauty itself (auto kalon) or the idea of beauty itself (idea autou kallous $-R$. 479a 1-2), and this object is something one (hen) and non-relative (aei kata tauta hōsautōs on $-R$. 479e 7-8). In juxtaposition to it, the object of belief is a plurality and it is relative, and sound or colour are examples of it ( $R .480 \mathrm{a} 2)$. In Book VI, a point of departure for the discussion, a slightly different dichotomy can be found. In the famous metaphor of the line, ${ }^{30}$ Plato starts from the difference between the believable (doxaston) and the knowable (gnōston). The first is connected with sensual experience (horōmenon) and it is unclear and untrue. The second is joined with intellectual cognition (nooumenon, noèton) and it is clear and true ( $R$. 509d 9; 510a 9). Finally, as is well known, there are four states of soul (pathēmata en tēi psuchēi) in the metaphor of the line: noessis and dianoia are the contents of mental activity; pistis and eikasia are in the area of sensory perception $(R$. 511d 8 - e 2). The objects of eikasia are images (eikones) of which examples are shadows or reflections in the water $(R$. $509 \mathrm{e} 1-510 \mathrm{a} 3)$. The objects of pistis are things which are the sources of shadows and reflections, i.e., plants or the objects of craft ( $R$. 510a 5-6). The characteristic of dianoia includes both the object and the activity. Hypotheses ${ }^{31}$ are the starting point

"totally"; J. Annas (An Introduction, p. 196): "fully"; S. BenARdete (Socrates Second Sailing. On Plato's Republic. Chicago-London 1989, p. 136): "perfectly"; K. DORTER (The Transformation of Plato's Republic. Lanham-Boulder-New York-Toronto-Oxford 2006, p. 153): “completely”; S. Rosen (Plato's Republic. A Study. New Haven-London 2005, p. 218): "entirely"; É. Chambry (Plato: Oeuvres Completes. vol. VII.1. Paris 1933, p. 93): "absolument"; R.K. Maurer (Platons 'Staat' und die Demokratie. Berlin 1930, p. 230): "vollkommen."

${ }^{29}$ It is worth mentioning that the difference between knowledge and belief can be used as an argument for the existence of ideas. See Pl., Ti. 51d 3-7: "If understanding and true opinion are distinct, then these 'by themselves' things definitely exist — these Forms, the objects not of our sense perception, but of our understanding only. But if - as some people think - true opinion does not differ in any way from understanding, then all the things we perceive through our bodily senses must be assumed to be the most stable things there are" (translated by D.J. ZEYL).

${ }^{30}$ A summary of the studies up to the mid-1980s can be found in: Y. Lafrance: Pour intrepréter Platon. Vol. I: La ligne en République VI, 509d-511e. Bilan analytique des études (1804-1984). Montréal 1987.

31 W.D. Ross (Plato's Theory of Ideas. Oxford 1951, p. 51) suggests that they have an existential character. 
of dianoia, i.e., something that is not only undefined (oudena logon didonai) but also unjustified, ${ }^{32}$ and this mental operation heads consequently (homologoumenos) from the hypotheses to an end. Examples of hypotheses are the even, the uneven, three forms of the angles and the shapes ( $R$. 510c 4-5). The demonstration objects for dianoia are the square itself (tetragonon auton) or the diagonal/diameter itself (diametros aute $-R$. $510 \mathrm{~d} 7-8$ ). ${ }^{33}$ As can be seen, Plato uses the pronoun autos, $-\bar{e}$, -on to describe the object of mathematics, which is generally reserved for the ideas in his philosophy. This raises the question of whether the mathematician takes up the ideas. Summarising his teacher's philosophy, Aristotle states that

apart from the both perceptibles and the Forms are the objects of mathematics $[\ldots]$ which are intermediate between them, differing from the perceptible ones in being eternal and immovable, and from the Forms in that there are many similar ones, whereas the Form itself in each case is one only (Metaph. 987b 14-18, trans. C.D.C. Reeve).

\section{Middle and late dialogues of Plato}

In the Republic (R. 511d 4), mathematics is also "between," but it is between pistis and nous. ${ }^{34}$ The latter has a common starting point with

32 R.M. Hare (Plato and the Mathematicians. In: New Essays on Plato and Aristotle. Ed. R. Brambough. London 1965, pp. 21-22) thinks that it is only about lack of the definition.

33 As is well known, Plato stresses that there is a connection between mathematics and the sensual world. It is stated in the Republic that mathematicians can illustrate mathematical objects by, for example, drawing a square on the sand. But they are aware that the proper object of their activity is the square in the mind and not the drawn one. The deeper connection between mathematics and the material reality can be found in the Timaeus, where geometry is the essence of the material being (Ti. 53c ff.). Every bodily being can be reduced to the four elements that are physical manifestations of the four socalled "platonic solids" and they can be reduced to the two basic forms of the triangle rectangular and equilateral. That is why mathematics is a "bridge" between the sensory and the intellectual spheres. See J.S. Morrison: Two Unresolved Difficulties in the Line and Cave. "Phronesis" 1977, no. 22, p. 231.

34 This position of mathematics is certainly opposed to the Democritean and Protagorean beliefs concerning this science; see Arist., Metaph. $997 \mathrm{~b} 32$ ff. = DK 80 B 7; W.D. Ross: Aristotle's Metaphysics. Vol. I. Oxford 1924, p. 232. 
dianoia - the hypothesis, but its activity is first directed at something higher - to something not hypothetical (anupotheton) and to the principle of the whole (tou pantos archē) - and then nous descends to the Forms and uses only Forms themselves $(R .511 \mathrm{~b} 6-\mathrm{c} 2)$. The ability to ascend and to descend is nothing other than dialectics (dunamis tou dialegesthai), i.e., the kind of knowledge which enables the logos itself to see noetic being (R. 511c 5-6). So, Plato also uses the pronoun autos to specify a special activity of reason. When it works itself, it is separated from sensual data. When it considers itself a quadrilateral, it makes it without physical images. When this activity is undertaken by the logos of a mathematician who is not able to rise above the hypotheses, the mathematics is simply a kind of skill (techne $-R$. 511c 6). The truth of mathematical theses is only relative and not absolute because it is relative to the accepted hypotheses and the process of deduction. The knowledge of the mathematician is not as clear as the knowledge of the philosopher and one can hazard a guess that the former could be treated as a belief. ${ }^{35}$ This is why Plato shows that hypotheses need to be justified and this justification comes from disciplines other than mathematics. When a mathematical activity is undertaken by a mathematician-philosopher, a given form of mathematical knowledge is not only coherent but also fully well-founded through dialectical knowledge. Mathematical beings and the principles then constitute epistēme. ${ }^{36}$ This does not mean that the difference between mathematics and dialectics is razed. It should not be forgotten that a hypothesis in mathematics

35 One may object to this hypothesis but it seems that a mathematician as mathematician does not know which hypotheses are justified and which are (probably) not. Nothing precludes the possibility that a new hypothesis is added or an old hypothesis is changed especially since the deductive model of mathematics was still in statu nascendi in Plato's time.

${ }^{36}$ In the Republic, there are geometrical beings and the numbers themselves $(R .525 \mathrm{~d}$ 6). In the Phaedo, there are two important statements about mathematics. There are the undivided and non-added numbers (Phd. 96e-97b) and the number is the number thanks to participation (metaschesis) in the given being-essence (ousia), e.g., the number two is two thanks to its participation in the duas (Phd. 101c 2-5). This is probably connected with the so-called agrapha dogmata of Plato. In this theory, Plato accepted two kinds of numbers: mathematical and ideal. The latter is not a multitude of unities, but rather it is an undivided and non-added whole. There are only ten ideal numbers and they are inferred from the two highest principles: the one (hen) and the indefinite dyad (aoristos duas). For more on this, see: K. GAISER: Platons Ungeschriebene Lehre. Studien zur systematischen und geschichtlichen Begründung der Wissenschaften in der Platonischen Schule. Stuttgart 1963, p. 115 ff.; W. BuRKerT: Lore and Science in Ancient Pythagoreanism. Cambridge 1972, pp. 15-28; G. Reale: Per una nuova intepretazione di Platone. Milano 2003, p. 228 ff.; B. Dembiński: Późna nauka Platona. Związi ontologii i matematyki. Katowice 2003, p. $81 \mathrm{ff}$. 
need not be justified and it is a self-evident principle. A philosopher finds a real hypothesis (tōi onti $-R$. 511b 5) qua hypothesis which needs to be justified by something non-hypothetical. According to Plato, mathematical operations consist in examination and searching (skepsis $-R$. 510d 3; $z \bar{t} t \bar{e} s i s-R$. 511a 4) which is necessary and coherent, whereas the philosophical activity is to grasp and to contemplate (haptesthai $-R$. $511 \mathrm{~b}$ 4-7; theōrein $-R$. 511c 6). For a mathematician, mathematical objects are self-evident (panti phanera $-R$. 510d 1; enargeis $-R$. 511a 8) and selfsufficient (auta), i.e., they do not need to be justified, but the philosopher is aware that mathematical hypotheses must be justified by higher principles which are really self-sufficient (auta dia auta $-R$. 511c 2). But three questions need to be explained:

(1) what are the above-hypothetical beings;

(2) what can be said about the method which enables one to go beyond the hypotheses and to go back to them;

(3) what is the non-hypothetical - the principle of all.

As far as (3) is concerned, it is universally accepted that Plato has the idea of the good in mind. ${ }^{37}$ As for the method mentioned in (2), the Republic offers no description of how to go beyond the mathematical hypotheses. It is important to say more what kind of hypotheses could be accepted in Plato's time. W.R. Knorr states that in Euclid's Elements, books I, III and VI contain the earliest, Ionian form of Greek geometry. Its beginnings can be dated back to Thales and Oenopides, and it was presented for the first time as an organized structure by Hippocrates of Chios. ${ }^{38}$ In the first book for example, a point (sēmeion - def. 1), a line (grammē - def. 2), a plane (epiphaneia - def. 5), three angles (def. 10, 11, 12), a shape (def. 14), a diameter (def. 17) and a quadrilateral (def. 19) are defined. On the other hand,

37 See, e.g., W.D. Ross: Plato's Theory of Ideas, p. 54; R. Robinson: Plato's Earlier Dialectic, p. 160; I.M. CrombiE: An Examination of Photos Doctrines, Vol. II, p. 550 ff.; J.E. Raven: Plato's Thought in the Making. Cambridge 1965, p. 162; K. Gaiser: Platons Ungeschriebene Lehre, pp. 91-95; J. Halfwassen: Der Aufstieg zum Einen. Untersuchungen zu Platon und Plotin. Stuttgart 1992, p. 20; J. GAJDA: Platońska droga do idei. Aksjologiczny rodowód platońskiej ontologii. Wrocław 1993, p. 93; H.-G. GADAMER: Idea dobra $w$ dyskusji między Platonem a Arystotelesem. Trans. Z. Nerczuk. Kęty 2002, p. 64; H.J. Krämer: Die Idee des Guten. Sonnen- und Linengleichniss. In: Platon. Politeia. Ed. O. HöFFE. Berlin 2005, p. 192.

38 W.R. Knorr: The Evolution of the Euclidean Elements. A Study of the Theory of Incommensurable Magnitudes and Its Significance for Early Greek Geometry. Dodrecht 1975, p. 306. B.L. VAN Der Waerden, Science Awakening. Trans. A. Dresden. Groningen 1954, p. 135. T. Heath (A History of Greek Mathematics. Vol. I: From Thales to Euclid. Oxford 1921, p. 374) thinks that definitions 4 and 7 came into being in Plato's time and the others are earlier. 
the seventh book includes the definitions of a unit (def. 1), a number (def. 2), an even (def. 6) and an uneven number (def. 7). Historically, this book likely contains the findings of Theaetetus, a mathematician closely related to Plato's school..$^{39}$ If Knorr is right, the philosopher-dialectician should be able to go beyond the above-mentioned hypotheses. But is it possible to find the traces of such a procedure in Plato's dialogues?

In the fullest possible way, mathematics was used by Plato in the Timaeus. Since a detailed presentation of the difficult and often unclear arguments contained in this dialogue would go too far beyond the framework of this paper, only the most important elements will be presented that will allow for a clarification of the Platonic concept of knowledge. ${ }^{40}$ For Plato, the universe has a spiritual and bodily dimension and it is a reflection of the noetic sphere. Its soul and body are the work of Demiurge. The first was created from what is divisible (meriston) or the other (heteron) and indivisible (ameriston) or the same (tauton) and from what is mixed with both. The resulting entity was divided again and combined into a harmonious whole (Ti. 35a-36b), i.e., the parts are arranged in a geometric series in which harmonic and arithmetic means are inserted. ${ }^{41} \mathrm{~A}$ feature of matter is being three-dimensional, i.e., being solid. Each solid consists of surfaces and they can be assembled, according to Plato, of triangles (Ti. 53c-d). Plato does not explicitly say that the triangles could also be constructed but he seems to allude to that: "[...] but the principles which are still higher than these are known only to God and the man who is dear to God" (Ti. 53d 6-7; trans. R.G. Bury).

This enigmatic comment can mean that one should look for these principles outside Plato's dialogues, in the so-called "unwritten doctrine." From the testimonies, ${ }^{42}$ we learn it carried out a deeper dimensional reduction

39 W.R. KNORR: The Evolution, p. 273.

40 The disputes over the interpretation of this dialogue date back to antiquity, i.e., to the first generation of Plato's successors: Xenocrates and Crantor. Contemporary literature on this dialogue is enormous; see, e.g., A.E. TAYLOR: A Commentary on Plato's Timaeus, Oxford 1928; Interpreting Timaeus - Critias. Eds. T. CAlvo, L. Brisson. Sankt Augustin 1997; Le Timée de Platon. Contributions a l'historie de sa reception. Platos Timaios. Beiträge zu seiner Rezeptionsgeschichte. Ed. A. NeschKe-Hentschke. Louvain-Paris 2000; T.K. Johansen: Plato's Natural Philosophy. A Study of the Timaeus-Critias. Cambridge 2004.

41 A. BARKer: Three Approaches to Canonic Division. "Apeiron" 1991, no. 24, p. 68 ff.; M. von Perger: Die Allseele in Platons Timaios. Stuttgart_Leipzig 1997, p. $74 \mathrm{ff}$.

42 See: K. GaISER: Platons Ungeschriebene Lehre; J.N. Findlay: Plato. The Written and Unwritten Doctrines. London 1974; M.-D. Richard: L'esignement oral de Platon. Paris 1986; H.J. KRÄMER: Platone e i fondamenti della metafisica. Milano 1992. 
than the one presented in the Timaeus. A solid can be reduced to planes and the planes, in turn, to sections. However, there is something else that is earlier and that is the principle of that geometrical order, namely, undefined spatiality ${ }^{43}$ which enables geometric thinking at all. This principle is called the "indefinite dyad" (aoristos duas) in the unwritten doctrine and its function is to double or to multiplicate. It needs to be marked by another principle - unity (to hen). The representation of unity in the geometrical order is probably a point and when it is connected with the undefined spatiality, it makes the space definite because every point of this space can be circumscribed with reference to this point. So, Plato shows that something that is non-hypothetic for a geometrician does in fact need a justification. He could conclude that the geometrical definitions are only hypothetical through their analysis. Let us take a look at two examples:

Def. 1: "A point (sêmeion) is that which has no part." To understand this, one needs to be able to discern what a part is. ${ }^{44}$

Def. 2: "A line (a section - grammē) is breadthless longitude (mēkos)." To understand this, one needs to understand what breadth and longitude are.

In the Elements, there is also no explanation of the definitions' order and number. ${ }^{45}$ The philosopher, however, justifies this order by dimensional reduction. The reduction is carried out on the object level, and its equivalent on the epistemological level is an analysis. The reverse procedure then is the construction of being from the principles and deduction. The acceptance of an undefined dyad as a principle of an undefined (infinite) multiplicity indicated the necessity of another mathematical reform, namely the rejection of the notion of a point and its replacement with the notion of a segment, since the segment-line appearing thanks to the dyad defines it and grants it the characteristics of divisibility. From the Parmenides dialogue (Prm. 137d138a), we learn that what has no part is infinite and indefinite (apeiron) geometrically (without beginning, end, middle; without shape; without position), and thus basically, it is what is non-geometric. It seems then that in the area of beings, there would be no such thing as a mathematical point. ${ }^{46}$

${ }^{43}$ Z. KróL: Platon i podstawy matematyki wspótczesnej. Pojęcie liczby u Platona. Nowa Wieś 2005, p. 96.

${ }_{44}$ See the discussion in Theaetetus $204 \mathrm{~d}-205 \mathrm{a}$.

45 What is interesting is that some of the definitions are not used at all. In geometry, the so-called "postulates" (aitēmata) are also accepted, i.e., the theorems are accepted without proof (in Book I of Elements, there are five of them; all of them - except postulate 4 - are constructions) and there are also general terms (koinai ennoiai - and those in Book I are also five). The postulates were probably written by Euclides, but the general concepts may be later. See T. Heath: A History, vol. I, pp. 375-376.

${ }_{46}$ The issue of the indivisibility in Plato's philosophy is very controversial. I agree with R. Sorabji's findings; see R. SorABJI: Time, Creation, Continuum. Theories in 
The discussion in the Timaeus also shows that the arithmetical order is important and the concept of a number is something fundamental. The oldest definition of a number (dating to the Pythagoreans and perhaps even Thales $^{47}$ ) says that it is a connection of units. The numbers are divided into even and uneven, and an even sequence starts from 2 , and the uneven from $3 .^{48}$ The number 1 is not a number and it is a non-arithmetical being (it can be called a logical predicate ${ }^{49}$ ). It serves to make other numbers: through its addition to even, an uneven number is made, and through its addition to uneven, an even number is made..$^{50}$ As it was said, Plato calls this basic division of the numbers is called a hypothesis. The fundamentals of arithmetic can be found in the seventh book of the Elements:

Def. 1. A unit is that by virtue of which each of the things that exist is called one.

Def. 2. A number is a multitude composed of units.

Def. 3. A number is a part of a number, the less of the greater, when it measures the greater;

Def. 4. but parts when it does not measure it.

Def. 5. The greater number is a multiple of the less when it is measured by the less.

Def. 6. An even number is that which is divisible into two equal parts.

Def. 7. An odd number is that which is not divisible into two equal parts, or that which differs by a unit from an even number" (trans. T.L. Heath).

The first two definitions do not play a major role in the proofs carried out in Book VII. In definitions 2-7, however, the notions of "measure" and "being a measure," the "smaller - larger" relationship and subtraction are presupposed. One needs to remember that arithmetic operations were presented in geometric form, where the monad corresponded to a segment. When the irrationality of the hypotenuse was discovered, it appeared not

Antiquity and the Early Middle Ages. London 1983, pp. 358-359.

47 Iamb. In Nic. 10, 8-10: "Thales defines quantity, which is a number, as the set of monads (sustēma monadōn)"; trans. A.P.

48 See DK 44 B 5; Arist. Metaph. 986a 17-18; Nicomachus of Gerasa: Introduction to Arithmetic, I 7, 1.

49 Z. Król: Platon i podstawy, p. 29.

50 Archytas and Philolaus were probably already aware of this otherness of the number 1; DK 47 A 4; DK 44 B 5. For more on this, see C.A. Huffman: Philolaus of Croton. Pythagorean and Presocratic. Cambridge 1993, p. 177 ff.; C.A. Huffman: Archytas of Tarentum. Pythagorean, Philosopher and Mathematician King. Cambridge 2005, p. 485 ff. 
only that a monad is really not a number, but also that there is a segment which cannot be measured by units. ${ }^{51}$

Mathematics in this form cannot be a basis for knowledge, it must be grounded and, as it turned out, reformed. It found its basis in two already mentioned principles: unity and undefined dyad, and the theory of ideal numbers. The latter, as we try to reconstruct it on the basis of indirect proofs, are generated from principles, most probably thanks to the method of diaeresis. ${ }^{52}$ Without going into the details of this concept, what is important is that Plato noticed what is not arithmetical in arithmetic and he pointed out that it somehow funds and conditions as a principle the whole sphere of human intellectual activity. The project to find a definitive justification for human knowledge and to revise its present form did not, however, involve only mathematical order, although, in this respect, it turned out to be fundamental. For Plato, the sphere of values can be considered the most important.

The discussion on values permeates most of the writings of the founder of the Academy. Plato searches for the definition of virtues, considers the possibility of shaping the human character so that virtues can be realized in it, and finally postulates the existence of such beings as the idea of beauty (Symposium), justice (Phaedrus) or goodness. He introduces the last idea in the Republic. The Good becomes that thanks to which every human being has the power/capacity (dunamis) of cognition, and this dunamis connected with the truthfulness (the true object of cognition) gives him or her knowledge. The object of cognition obtains truthfulness, to be recognized (gignōskesthai), to be (einai) and being (ousia) from the Good. The Good itself is also above the ideas (epekeina tès ousias) (R. 507a-509d).$^{53}$ Why does the Good create knowledge? Plato gives the following explanation: "the form of the good is the most important thing to learn about (megiston mathèma) and that it's by their relation to it that just things and the others become useful and beneficial (chrēsima kai öphelima)" (R. 505a; trans. G.M.A. Grube). Thinking in Platonic categories: a good car is an efficient car (capable of carrying people or things), that is, a useful car; however, a car is a car because it is a four-wheeled vehicle equipped with an engine.

${ }^{51}$ For more on this, see A. SzaBó: The Beginnings of Greek Mathematics. Budapest 1978.

52 See Porphyry's and Alexander of Aphrodisias's reports in Simplicius's Commentary on Aristotle's "Physiscs" 453, 22-455, 1 (=23B Gaiser).

53 This does not mean that the Good is transcendent over the already transcendent ideas; see R. FERBER: L'idea del bene è o non è transcendente? Ancora su epekeina tès ousias. In: Platone e tradizione platonica. Studi su filosofia antica, Eds. M. BonazzI, F. Trabattoni. Milano 2003, p. 127-149. 
The value of being useful is something added here, but it is so important that it is able to "activate" the cognitive structures of a human being: "Every soul pursues the good and does its utmost for its sake. It divines that the good is something but it is perplexed and cannot adequately grasp what it is..." (R. 505d $11-\mathrm{e} 2$, trans. G.M.A. Grube). When the senses attain the object, ${ }^{54}$ the process of building expertise about it begins; when a mind achieves an idea or ideas, cognition finds its fulfilment and it can be said that someone has Knowledge. Knowledge is like its object, i.e., eternal, unchanging, true and real, but it is also something more. It is good and its being good is anchored "beyond" the given idea(s) in the Good Itself. So, the idea of the Good is a distinguished element in Plato's philosophy similar to the principles of the unwritten teaching.

But Plato encountered difficulties in his theory, which are presented in the Parmenides. It turned out that some of the predicates of ideas (e.g., indivisibility or non-relativity) could create contradictions both in the theory of ideas and in the concept of knowledge. This seems to be why Plato searched for something higher than the ideas, started to consider whether there was an idea for any multitude of objects ${ }^{55}$ and the main scientific method was a dichotomous division (diairesis). ${ }^{56}$ This method is based on the synoptic and diaeretic procedure and enables one to see the hierarchical order between the notions and relations between them (genus - species order), to formulate definitions and to grasp the essence of a thing(s). The discussion with the sophistic movement and on the nature of language (Cratylus) made Plato aware that the division cannot be arbitrary and the definition should describe the real being (Sph. 221c), and the real first of all is what is natural. An example can be found in the Timaeus (39e-40a): the alive contains the immortal (gods) and mortal beings. The latter is divided into flying beings, swimming beings, and beings that move on land. The latter is then divided into rational and non-rational beings. The former, in turn, is divided into man and woman. In the case of Plato's philosophy, such a model of knowledge can be encapsulated from a static and dynamic

${ }^{54}$ In spite of the fact that sense perception is here the starting point, knowledge cannot be reduced to it, which Plato states clearly in the Theaetetus. The first part of this dialogue $(151 \mathrm{e}-187 \mathrm{~d})$ is devoted to the relation between knowledge and perception (aisthesis). Plato considers the questions of the subjectivity and variability of the perception and the individuality of its object. These three positions are represented by the sophist Protagoras, Heracliteans and Theaetetus, and all three are criticized by the founder of the Academy.

55 This pertains particularly to something described in negative way (e.g., not-beautiful, not-good). The consequence is the elimination of the "non-being" category through its reduction to the "difference" category in the Sophist.

56 See Pl., Phdr. 265d-e; Sph. 253d; Pol. 285b; Phlb. 16a-17a. It should also be mentioned here that Plato allows for non-dichotomous divisions. 
perspective. Knowledge is a full system of the relations between the genus and species in the whole of nature. This project is maximalist (it can be called a strong concept of knowledge), and it probably represents something that can be called divine knowledge. From the dynamic perspective, there are a method and the hypotheses at the philosopher's disposition and every single discovery can be methodically reduced to the hypotheses and be appropriately placed within the scope of the current partial knowledge (a weak concept of a knowledge). But is the partial knowledge real knowledge or an opinion $($ doxa $) ?^{97}$

Plato discusses the problem of whether knowledge is true opinion or true opinion with logos in the second and third part of Theaetetus (187e-201d), which is an aporetic dialogue, i.e., it ends without positively resolving the issue. If a true opinion has a propositional character and it is knowledge of a thing, then this knowledge precedes the opinion. Even if the true opinion was supplemented by the logos which could be an explanation of the difference (diaphorotêtos hermèneia), the knowledge of the difference would precede this doxa alèthès meta logou. Similarly to the Cratylus, where the problem of meaning in language cannot be positively solved in the language, it appears in the Theaetetus that the propositional knowledge called true opinion cannot be sufficiently determined in a propositional way. In both cases, it is necessary to grasp something beyond language, beyond proposition and extra-mental. This leads to the following questions: how can one's mind gain access to the non-sensual and extra-mental sphere? How is the sensual world conditioned by this sphere? Plato's answer to the first question would be the theory of recollection and to the second - the theory of participation. It is also probable that Plato attempted to infer the whole of reality from the first principles but this attempt was not successful, because according to the ancient testimonies, his successors were the first ones who succeeded in doing so.

57 This problem seems to appear already in the Symposium (Smp. 202a) where Diotima says that there is something between wisdom and ignorance, and it is the right opinion (orthe doksa) which is something true even though no reason can be given for it (aneu tou echein logon dounai). The example could be taken as a definition of being happy (Smp. 205a): "the happy are happy by acquisition of good things, and we have no more need to ask for what end a man wishes to be happy, when such is his wish: the answer seems to be ultimate" (trans. R.G. Bury). 


\section{Conclusion}

After Plato's ideas on knowledge are outlined, it is possible to return to the questions posed at the beginning of the paper. It seems that Plato is not the author of a consistent system of a theory of knowledge. He accepted something that could be called innatism and apriorism. However, we do not know precisely what is innate for Plato - concepts, knowledge as a whole, or the disposition to have knowledge? ${ }^{58}$ There is also no consistent description of the process of recollection in his dialogues. Plato is an apriorist, but this apriorism does not seem to be a methodological dimension of his philosophy. Is Plato an irrationalist for whom knowledge is contemplation? This is indeed what many researchers suggest. ${ }^{59}$ Plato can be understood as an epistemological fundamentalist, but only in the weak sense. His philosophy seems to be a scientific project. He called for the existence of an unshakeable basis of knowledge, but the first discovery - ideas - did not fulfil the postulate and the theory of the unwritten teaching was probably unfinished. Woleński does not, however, take into consideration another possibility. One needs to remember that there was already a dispute in Antiquity as to whether Plato was a sceptic or a dogmatic. ${ }^{60}$ Settling this dispute depends naturally on the definition of both terms. But if it is possible to read his philosophy as sceptical (and many of the statements in the dialogues seem to confirm that, e.g., the monologue of Timaeus is described as a probable account [eikos logos]), to pass it over is the weakest feature in Woleński's interpretation of Plato's philosophy.

58 For more on this, see G. FInE: The Possibility of Inquiry. Meno's Paradox from Socrates to Sextus. Oxford 2014, p. 140 ff.

59 See, e.g., I.M. Crombie: An Examination, vol. I. p. 65, 192, 316; Z. DANeK: Myśle, więc nie wiem. Próba interpretacji platońskiego dialogu „Teajtet”. Łódź 2000, p. 249; R. Rhees: In Dialogue with Greeks. Vol. II: Plato and Dialectic. Aldershot-Burlington 2004, p. 144; R. Spaemann: Die Philosophenkönige. In: Platon. Politeia, p. 130.

60 Diogenes Laertius: Vitae philosophorum, III 51; Sextus Empiricus: Pyrrhoniae hypotyposes, I 33. 


\section{Bibliography}

Annas J.: An Introduction to Plato's Republic. Oxford 1981.

Audi R.: Epistemology. A Contemporary Introduction to the Theory of Knowledge. London-New York 1998.

BArker A.: Three Approaches to Canonic Division. "Apeiron" 1991, no. 24, pp. $49-83$.

Benardete S.: Socrates Second Sailing. On Plato's Republic. Chicago-London 1989.

Benson H.H.: Socratic Wisdom. Model of Knowledge in Plato's Early Dialogues. Oxford 2000.

Brandwood L.: Stylometry and Chronology. In: The Cambridge Companion to Plato. Ed. R. Kraut. Cambridge 1992, pp. 90-120.

Brickhouse T.C., Smith N.D.: Plato's Socrates. Oxford 1994.

Burkert W.: Lore and Science in Ancient Pythagoreanism. Cambridge 1972.

Calvo T., Brisson L. Eds.: Interpreting Timaeus-Critias. Sankt Augustin 1997.

Catana L.: The Historiographical Concept "System of Philosophy." Its Origin, Nature, Influence and Legitimacy. Leiden-Boston 2008.

Crombie I.M.: An Examination of Plato's Doctrines. Vol. I: Plato on Man and Society. London 1962.

Crombie I.M.: An Examination of Plato's Doctrines. Vol. II: Plato on Knowledge and Reality. London-New York 1963.

Cross R.C., Woozley A.D.: Plato's Republic. A Philosophical Commentary. London 1964.

Curley E.: Rationalism. In: A Companion to Epistemology. Eds. J. Dancy, E. Sosa, M. Steup. Malden-Oxford-Chichester 2010, pp. 659-663.

DANeK Z.: Myślę, więc nie wiem. Próba interpretacji platońskiego dialogu Teajtet. Łódź 2000.

Dembiński B.: Późna nauka Platona. Związi ontologii i matematyki. Katowice 2003.

Diels H., Kranz W.: Die Fragmente der Vorsokratiker. Vol. I. Berlin 1951.

DORTER K.: The Transformation of Plato's Republic. Lanham-Boulder-New York-Toronto-Oxford 2006.

Erler M.: "Socrates in the Cave." Argumentations as Therapy for Passions in Gorgias and Phaedo. In: Plato Ethicus. Philosophy is Life. Eds. M. Migliori, L.M. Napolitano Valditara. Sankt Augustin 2004, pp. 107-120.

FERBER R.: L'idea del bene è o non è transcendente? Ancora su epekeina tès ousias. In: Platone e tradizione platonica. Studi su filosofia antica. Eds. M. BonAzzI, F. Trabattoni. Milano 2003, pp. 127-149.

Findlay J.N.: Plato. The Written and Unwritten Doctrines. London 1974.

Fine G.: The Possibility of Inquiry. Meno's Paradox from Socrates to Sextus. Oxford 2014. 
Gadamer H.-G.: Idea dobra $w$ dyskusji między Platonem a Arystotelesem. Trans. Z. NerCZUK. Kęty 2002.

GAISER K.: Platons Ungeschriebene Lehre. Studien zur systematischen und geschichtlichen Begründung der Wissenschaften in der Platonischen Schule. Stuttgart 1963.

Gajda J.: Platońska droga do idei. Aksjologiczny rodowód platońskiej ontologii. Wrocław 1993.

Guthrie W.K.C.: The History of Greek Philosophy. Vol. IV: Plato: the Man and His Dialogues. Earlier Period. Cambridge 1975.

Halfwassen J.: Der Aufstieg zum Einen. Untersuchungen zu Platon und Plotin. Stuttgart 1992.

Hare R.M.: Plato and the Mathematicians. In: New Essays on Plato and Aristotle.

Ed. R. Brambough. London 1965, pp. 21-38.

HeAth T.: A History of Greek Mathematics. Vol. I: From Thales to Euclid. Oxford 1921.

Huffman C.A.: Archytas of Tarentum. Pythagorean, Philosopher and Mathematician King. Cambridge 2005.

Huffman C.A.: Philolaus of Croton. Pythagorean and Presocratic. Cambridge 1993.

Irwin T.: Plato's Ethics. Oxford 1995.

Irwin T.: Plato's Moral Theory. The Early and Middle Dialogues. Oxford 1977.

Johansen T.K.: Plato's Natural Philosophy. A Study of the Timaeus-Critias. Cambridge 2004.

Kahn C.H.: A Return to the Theory of the Verb Be and the Concept of Being. In:

C.H. KaHn: Essays on Being. Oxford 2009, pp. 16-40.

Kahn C.H.: Did Plato Write Socratic Dialogues. "Classical Quarterly" 1981, no. 31, pp. $305-320$.

KaHn C.H.: On the Relative Date of the Gorgias and the Protagoras. "Oxford Studies in Ancient Philosophy" 1988, no. 6, pp. 87-88.

KnORR W.R.: The Evolution of the Euclidean Elements. A Study of the Theory of Incommensurable Magnitudes and Its Significance for Early Greek Geometry. Dodrecht 1975.

Krämer H.J.: Die Idee des Guten. Sonnen- und Linengleichniss. In: Platon: Politeia. Ed. O. HöFfE. Berlin 2005, pp. 135-154.

KräMer H.J.: Platone e i fondamenti della metafisica. Milano 1992.

Kraut R.: Comments on Gregory Vlastos, "The Socratic Elenchus." "Oxford Studies in Ancient Philosophy" 1983, no. 1, pp. 59-70.

Król Z.: Platon i podstawy matematyki współczesnej. Pojęcie liczby i Platona. Nowa Wieś 2005.

Lafrance Y.: Pour intrepréter Platon. Vol. I: La ligne en République VI, 509d-511e. Bilan analytique des études (1804-1984). Montréal 1987.

Maurer R.K.: Platons 'Staat' und die Demokratie. Berlin 1930.

Morrison J.S.: Two Unresolved Difficulties in the Line and Cave. "Phronesis" 1977, no. 22, pp. 212-231. 
Morrow G.R.: Plato's Cretean City, A Historical Interpretation of the Laws. Princeton 1993.

Nehamas A.: Socratic Intellectualism. "Proceedings of the Boston Area Colloquium in Ancient Philosophy" 1986, no. 2, pp. 275-316.

Neschke-Hentschke A. Ed.: Le Timée de Platon. Contributions a l'historie de sa reception. Platos Timaios. Beiträge zu seiner Rezeptionsgeschichte. LouvainParis 2000.

Pacewicz A.: O ewolucyjnym charakterze filozofii Platona. In: Philosophiae Itinera. Eds. A. Pacewicz, A. OlejarczyK, J. Jaskóla. Wrocław 2009, pp. 501—518.

Pacewicz A.: Wisdom - Knowledge - Belief. The Problem of Demarcation in Plato's Phaedo. "Studia Philosophica Wartislaviensia. Supplementary Volume. English Edition" 2013, pp. 11-23.

Penner T.: What Laches and Nicias Miss - and Whether Socrates Thinks Courage Merely a Part of Virtue. "Ancient Philosophy" 1992, no. 12, pp. 1-27.

Plato: Gorgias. Ed. E.R. DodDS. Oxford 1959.

Press G.A.: Preface. In: Plato's Dialogues. New Studies \& Interpretations. Ed. G.A. Press. Lanham 1993, pp. vii-ix.

Raven J.E.: Plato's Thought in the Making. Cambridge 1965.

Reale G.: Per una nuova intepretazione di Platone. Milano 2003.

Reale G.: Storia della filosofia antica. Vol. II. Milano $1988^{6}$.

ReEve C.D.C.: Socrates in the Apology. An Essay on Plato's Apology of Socrates. Indianapolis 1989.

Rhees R.: In Dialogue with Greeks. Vol. II: Plato and Dialectic. AldershotBurlington 2004.

Richard M.-D.: L'esignement oral de Platon. Paris 1986.

Robinson R.: Plato's Earlier Dialectic. New York 1941.

Rosen S.: Plato's Republic. A Study. New Haven-London 2005.

Ross W.D.: Aristotle's Metaphysics. Vol. I. Oxford 1924.

Ross W.D.: Plato's Theory of Ideas. Oxford 1951.

Rutherford R.B.: The Art. of Plato. Ten Essays in the Platonic Interpretation. Harvard 1995.

Salmon W.C.: Theory. In: A Companion to Epistemology. Eds. J. Dancy, E. Sosa, M. Steup. Malden-Oxford-Chichester 2010.

Sorabji R.: Time, Creation, Continuum. Theories in Antiquity and the Early Middle Ages. London 1983.

Spaemann R.: Die Philosophenkönige. In: Platon: Politeia. Ed. O. Höffe. Berlin 2005, pp. 121-134.

StróżeWSKi W.: Wykłady o Platonie. Ontologia. Kraków 1992.

SzaBó A.: The Beginnings of Greek Mathematics. Budapest 1978.

TARÁN L.: Platonism and Socratic Ignorance. In: Platonic Investigations. Ed. D.J. O’MeARA. Washington 1985, pp. 85-109.

Taylor A.E.: A Commentary on Plato's Timaeus. Oxford 1928.

van der Waerden B.L.: Science Awakening. Trans. A. Dresden. Groningen 1954.

Vlastos G.: The Socratic Elenchus. "Oxford Studies in Ancient Philosophy" 1983, no. 1, pp. $27-58$. 
von Perger M.: Die Allseele in Platons Timaios. Stuttgart—Leipzig 1997.

Williams M.: Skepticism. In: The Blackwell Guide to Epistemology. Eds. J. GreCo,

E. Sosa. Malden-Oxford 1999.

WoleŃsKi J.: Epistemologia. Vol. I: Zarys historyczny i problemy metateoretyczne.

Kraków 2000.

WoleŃSKI J.: Epistemologia. Vol. II: Wiedza i poznanie. Kraków 2001.

Woodruff P.: Plato's Early Theory of Knowledge. In: Ancient Greek Epistemology.

Ed. S. Everson. Cambridge 1990, pp. $60-84$.

Artur Pacewicz — doktor habilitowany w Instytucie Filozofii Uniwersytetu Wrocławskiego. 